\title{
Editorial
}

\section{CIRCULAR ECONOMY, METHANE EMISSIONS, WASTE MANAGEMENT, AND THE COURTS' ROLE}

Normally defined as a new and sustainable model of production and consumption, circular economy involves sharing, leasing, reusing, repairing, refurbishing and recycling existing materials and products as long as possible. The obvious aim is to extend the life cycle of products.

Under the European Green Deal and in line with a proposed new industrial strategy, in March 2020 the European Commission presented the new circular economy action plan (EU Circular Economy Action Plan, 2020). It is about product design, reducing waste and empowering consumers (e.g., via the introduction of a right to repair).

In February 2021 the Parliament adopted a resolution on the new circular economy action plan, demanding additional measures to achieve a carbon-neutral, environmentally sustainable, toxic-free and fully circular economy by 2050 , including tighter recycling rules and binding targets for materials use and consumption by 2030 .

\section{New EU Parliament strategy to reduce methane emissions}

While circular economy is mainly based on reducing waste to a minimum, this is not the end of the story.

All sustainable strategies are also based on the reduction of greenhouse gases' emissions, or on carbon sequestration, to directly tackle climate change.

In this context, concern is growing on methane emissions, as their permanence in the atmosphere is long.

Landfills and waste management in general are one of the potential sources of such emissions.

Consequently, on 21 October 2021 the EU Parliament approved a new strategy to reduce methane emissions (European Parliament, 2021). This strategy also contains rules related to waste.

In general, the strategy is based on the fact that methane is a powerful greenhouse gas, 80 times more potent than carbon dioxide (CO2) over a 20-year period, making it the second most important greenhouse gas, as well as a precursor pollutant to ground-level ozone (03) contributing to about a quarter of the global warming experienced today.

Thus, all scenarios aimed at meeting the $1,5^{\circ} \mathrm{C}$ target defined by the Intergovernmental Panel on Climate Change (IPCC) involve deep reductions of methane emissions. According to the UN Environment Programme (UNEP), reducing human-caused methane emissions by as much as 45 $\%$ will avoid nearly $0,3^{\circ} \mathrm{C}$ of global warming by the $2040 \mathrm{~s}$ and complement all long-term climate change mitigation efforts mainly based on $\mathrm{CO}_{2}$ emissions reduction. The Eu- ropean Green Deal (EU Green Deal, 2020) considers methane as the sector where the most cost-effective emissions savings can be achieved, while producing the quickest cooling effect.

\section{Methane emissions and waste management}

Agriculture still represents the largest share of anthropogenic methane emission sources in the EU. So much so that the use of agricultural waste and residues for biogas production is considered to be a driver for the circular economy, provided that the cascading use principle is adhered to and the appropriate sustainability criteria are applied.

Fugitive emissions from leaking equipment, infrastructure or closed and abandoned sites, as well as emissions from venting and the incomplete combustion of methane, represent the majority of methane emissions in the energy sector, by far the second most important methane emission source.

However, landfills of municipal solid waste have also been identified as a further significant source of methane, even if their role is much lower than that of agriculture and energy (Cossu et al., 2020).

Consequently, the EU Parliament new strategy on methane calls on the Commission to integrate a strong focus on methane emissions in the 2024 review of the Landfill Directive and the upcoming revision of the Industrial Emissions Directive. The strategy goes on by highlighting the need for measures to require landfill sites to use the bio-methane they produce until its energy content drops below a useful value and, once it is no longer viable to use the bio-methane produced at a landfill site, for the use of bio-oxidation and other technologies in hot spots in order to reduce the remaining methane emissions (Grossule and Stegmann, 2020).

After generally emphasizing that closure and after-care procedures for landfill cells are key to reducing leakages, taking into account the entire life cycle of landfill sites, the EU Parliament strategy generically affirms that "landfill disposal, which sits at the bottom of the waste hierarchy, is the most polluting way to manage waste both in terms of greenhouse gas emissions and other pollutants to air, soil and water".

Such an assertion seems to elicit - as Cossu (2020) puts it - "an idealistic order which is scarcely reliable to the real world" and to not take into account the virtuous role that, under strict conditions, sustainable landfills can 
play "in closing the material loop" as well as in working as a "carbon sink".

\section{Parliaments' and Courts' respective roles in tackling} climate change

The regulation of greenhouse gas emissions is continuously adding new targets for the Member States to reach. Goals to be achieved in terms of maximum temperature grow, minimum percentage of waste recycling, maximum (and very low) percentage of waste disposal in landfills.

This poses a crucial question to modern democracies, which is easy to ask, but difficult to answer. What happens when the States do not meet the required standards? What happens, in other words, if one or several Governments do not implement environmental policies which fully reach the required goals?

The enforcement tools provided for by international law are weak. At their very best, both the Paris Agreement and other environmental Treaties only make it possible either to implement further consultations with the non-compliant State or to ask some International Court to apply an economic fine to that State.

In the context of the traditional political doctrine of the "separation of powers" - which assumes the division of the legislative, executive, and judicial functions of government among separate and independent bodies - no other role can be played by the Courts.

However, such doctrine is being slowly but continuously challenged. In the Netherlands, in the United States of America, in Germany and in several other countries, Constitutional and Administrative Courts have decided to change the pace of Courts intervention with respect to political law-making (Kahl and Weller, 2021).

In different ways, all these decisions imposed to a Government to change its politics in the direction of more effectively tackling climate change, also by improving waste management.
This trend - known as climate litigation, or environmental litigation - tries to "boldly go where no one has gone before" (as the famous StarTrek captain said). But it poses serious questions to scholars of both law and environmental management.

To what extent is a given environmental risk so serious and imminent as to require to the Courts to force the traditional separation of powers? And, coming again to landfilling, to what extent can Courts assess the environmental equilibrium of Final Sorage Quality of a given landfill, if and when they are asked to enforce the theoretical targets established by EU law for landfills closure rates?

These questions call for further research, as well as for joint efforts by legal, technical and environmental experts, in order to establish consensus on the relationship between environmental policy-making and the Courts' role.

Luciano Butti

University of Padova, Italy

luciano.butti@buttiandpartners.com

\section{REFERENCES}

Cossu, R. (2020). The failure of geometry: time for gears! Detritus. 13, 1-2. doi:10.31025/2611-4135/2020.14034

Cossu, R., Grossule, V., \& Lavagnolo, M. C. (2020). What about residues from circular economy and role of landfilling? Detritus, 9, 1-3. doi:10.31025/2611-4135/2020.13920

EU (2020). Circular Economy Action Plan; https://ec.europa.eu/environment/strategy/circular-economy-action-plan_en

EU (2020) Green Deal; https://ec.europa.eu/info/strategy/priorities-2019-2024/european-green-deal_en

EU (2020). Strategy to Reduce Methane Emissions; https://ec.europa. eu/energy/sites/ener/files/eu_methane_strategy.pdf

European Parliament (2021). Resolution of 21 October 2021 on an EU strategy to reduce methane emissions; https://www.europarl.europa.eu/doceo/document/TA-9-2021-0436_EN.html

Grossule, V., Stegmann, R., 2020. Problems in traditional landfilling and proposals for solutions based on sustainability. Detritus, $12,78-91$. doi:10.31025/2611-4135/2020.14000

Kahl, W., Weller, M.P., (2021). Climate Change Litigation. A Handbook. Hart Publishing, ISBN 9781509948734 